\title{
Film and the Festival of Britain
}

\author{
SARAH EASEN
}

$\mathbf{T}$ He Festival of Britain, from 3 May to 30 September i95I, aimed to provide respite from the effects of World War II by celebrating the nation's past achievements in the arts, industry and science, as well as looking hopefully to a future of progress and prosperity. It marked the halfway point of the century, a natural moment at which to take stock and examine advances in British society. The Director General of the Festival, Gerald Barry, promised 'a year of fun, fantasy and colour', an interlude of 'fun and games' after the long run of wartime austerity. ${ }^{\text {' }}$

Film was integral to the Festival of Britain. It related to the Festival's three main areas of concern, the arts, industry and science. Britain's role in international film culture had already been established by the growth of the British documentary movement since the I930s. The Festival of Britain therefore seemed a natural place to demonstrate the fruits of British film production. The Festival of Britain site in London on the South Bank featured a purpose-built film theatre, the Telekinema, for big-screen public television broadcasts and the showing of specially commissioned Festival films. ${ }^{2}$ The Television Pavilion also displayed a brief history of the new medium. Cinemas around the nation featured seasons of classic British filmmaking. The exhibitions themselves also used film as a tool for expressing concepts and processes that could not easily be displayed. So film was not only a medium for the exposition of ideas within the Festival of Britain exhibitions, it also contributed to the entertainment on offer.

Originally the plan for a i95 I festival derived from the centenary of the Great Exhibition of $185 \mathrm{I}$ which showcased the achievements of newly industrialised Victorian society and its global empire. Gerald Barry, editor

\footnotetext{
I work for the British Universities Film and Video Council on their British Newsreels Project. I am currently researching British women non-fiction film-makers. My interest in the post-war modernisation of Britain led me to programme a season of films and curate an exhibition at the National Film Theatre for May 200 celebrating the fiftieth anniversary of the 195 I Festival of Britain. Sarah Easen
} 
of the left-wing News Chronicle, had championed the idea in 1945 . The government decided to set up the Ramsden Committee to investigate the idea of a 'Universal International Exhibition'. This was eventually downsized to a national exhibition and by 1948 the structures were in place to begin the planning phase by the Festival of Britain Office. On 5 May I948 the head of the Festival Council, Herbert Morrison, requested that the British Film Institute (BFI) organise the film side of the Festival. Jack Ralph, previously of the National Film Board of Canada, was appointed by the BFI in January 1949 as its representative responsible for all Festival film arrangements. To discuss the role of film in the Festival he established the BFI Festival of Britain 195I Panel consisting of prominent members of the British film industry, including Michael Balcon, Anthony Asquith, John Grierson, Harry Watt and Arthur Elton.

Initial plans were ambitious and many ideas had to be dropped due to logistical problems and financial restrictions. A proposed international conference of producers, directors and technicians was abandoned in June I949 after it was decided that I95 I should only be a celebration of national achievements. A two-week festival of British films for June 195I to be organised by the BFI at the New Gallery cinema in London was cancelled because the BFI was ineligible for exemption from Entertainments Duty and so could not afford the undertaking. During 1949 and 1950 the press reported that several of the large studios were making films for the Festival. ${ }^{3}$ Frank Launder was to make a Korda-produced film with action set during the Great Exhibition of i85. A non-profit making co-operative called Festival Film Productions was making The Magic Box, a biography of the British cinema pioneer, William Friese-Greene. Elstree was making The Elstree Story - a compilation of films made at the studio over the previous twenty-five years, as well as an adaptation of Thomas Hardy's The Mayor of Casterbridge starring Richard Todd. Powell and Pressburger were shooting Tales of Hoffman and Carol Reed was also rumoured to have something in the pipeline. In the event, many of these films never made it past pre-production in time for the Festival and only one was designated a Festival film, The Magic Box.

Documentary and experimental film-making initially fared better as the Festival Executive provided a $£_{120,000}$ budget for documentary film production. This was to be the seed for an idea that became the BFI's Experimental Film Fund, established in 1952. A sub-committee of the BFI Panel selected six themes for Festival-sponsored films: 'The Sea', 'The Land', 'The People, 'Royalty' (which included tradition and ceremony), 'Sport', 'The Great Road' (a study of one of Britain's arterial highways) and 'The River' (about the River Severn). ${ }^{4}$ Unfortunately the Festival Office withdrew this 
funding and in December 1949 the BFI Panel sub-committee metamorphosed into a new Committee of Sponsorship and Distribution to set about finding private and public sponsorship. Several established documentary units came to the rescue. The Shell Film Unit sponsored Air Parade. Humphrey Jennings's company, Wessex Film Productions, made Family Portrait. World Wide Pictures in conjunction with the Welsh Committee for the Festival of Britain financed David. International Realist made Waters of Time, which was sponsored by the Port of London Authority, and the Petroleum Films Bureau sponsored Forward a Century. However, there is evidence to suggest that the Festival Office later restored $£_{\text {II }, 000}$ worth of funding to the BFI, for producing several experimental films for screening at the Telekinema. ${ }^{6}$ These included four stereoscopic (3-D) and stereophonic films made under the guidance of Raymond Spottiswoode as well as the Painter and Poet series.

Not only were there problems with the pre-production of the films. Throughout 1949, the Festival Office and the BFI Panel could not agree on a suitable exhibition venue. When it was agreed that projection facilities should be included on the South Bank site, the panel complained that plans for a $45^{\circ}$-seat cinema were 'thoroughly inadequate'. ${ }^{7}$ However, the Festival Office duly appointed an architect, Dr W. Wells Coates, to design a building to accommodate the showing of $35 \mathrm{~mm}$ film, stereoscopic (3-D) and stereophonic film and large-screen television. By October $195^{\circ}$ a grey oblong building, constructed from light steel and soundproofed, in a 'fly-away linear design [with a] gay façade and bold modern stare', was nestled next to the railway arches between the Royal Festival Hall and Waterloo Station. ${ }^{8}$ This was the Telekinema. The seating capacity was $4 \mathrm{IO}$, that is, 252 in the stalls and 158 in the balcony. The projection booth, situated between the balcony and the stalls, was behind glass. Visitors could see the film and television operating equipment as they entered the foyer, which also doubled as a television studio. Here celebrities were interviewed and these interviews were later broadcast as part of the special Telekinema programme along with selected material from the BBC. The remainder of the one hour and ten minute programme was made up with showings of the sponsored documentaries and four stereophonic films. The Telekinema was a great success: 458,693 visitors paid the separate admission charge of $2 s$ and many people had to be turned away. ${ }^{9}$ When the Festival ended in the autumn, there were calls from the press and the public to retain several landmarks, of which the Telekinema was one. After much wrangling with the LCC and the film industry, the building was formally handed over to the BFI for use as a members-only repertory cinema club. It was re-equipped with four hundred 
seats and projection facilities for both $16 \mathrm{~mm}$ and $35 \mathrm{~mm}$, and was re-opened in October 1952 as the National Film Theatre. Five years later, the Telekinema building was closed when the BFI built its new cinema under Waterloo Bridge within a stone's throw of the old site.

The BFI Panel had strong ideas about using film in the displays. It was adamant that 'there should be facilities for continuous $16 \mathrm{~mm}$ showings in as many sections of the Exhibition as possible, the film in this case being treated as an integral and functional part of the particular exhibit concerned'. ${ }^{\circ}$ The panel minutes note that this recommendation should be taken up with the Festival Executive, suggesting that the executive did not realise the potential of film as a tool for instruction and education. However, $16 \mathrm{~mm}$ film replaced the stagnant display of manufactured products, the impracticality of working models and the static wall displays that were frequently used in exhibitions. The centrepiece of the Land of Britain pavilion was a pillar of rock representing geological evolution, which concealed a $16 \mathrm{~mm}$ projector showing a continuous film loop. This was projected on to a rubber screen, which transformed itself into a giant relief map every few seconds to show the birth of the nation. ${ }^{\text {II }}$ The Dome of Discovery made extensive use of I $6 \mathrm{~mm}$ film including the use of a micro-projector to show an enlarged image of the working parts of a watch. The New Schools Pavilion displayed a filmstrip projector and a $16 \mathrm{~mm}$ sound projector as invaluable teaching tools in the primary and secondary classroom exhibits. ${ }^{12}$ Educational films, a genre British film-makers had excelled in since the I930s, were screened at the Exhibition of Science in South Kensington. Their specially constructed onehundred-seat cinema showed a free continuous forty-minute programme of scientific films from I.०० p.m. every day for the duration of the festival.

Those concerned with the Festival's film arrangements wanted British cinematic achievements to be celebrated by the whole nation not just those who visited the London sites. A travelling Festival Exhibition visited Manchester, Leeds, Birmingham and Nottingham during the Festival period. It had a 'People at Play' section with a small cinema which featured sevenminute film shows every fifteen minutes: it was regularly packed out. The fifth Edinburgh International Film Festival devoted its annual retrospective to British documentary, which included screenings of Industrial Britain (193I) and Night Mail (1936). Special screenings of Festival films were also programmed and $16 \mathrm{~mm}$ prints of the stereoscopic films were shown twice nightly for the run of the film festival. Bath held an International Film Festival for children in May, and Glasgow hosted the 13 th International Amateur Film Festival during August. Less formal evaluations of British film-making were also taking place such as film festivals organised by local 
authorities. Newcastle-upon-Tyne screened a season of British scientific, documentary and industrial films in early June. ${ }^{13}$ The Barrow Arts Club sponsored a Festival of British Cinema which concluded with Paul Rotha's film A City Speaks (1948) and a session analysing Odd Man Out (1948). ${ }^{\text {I4 }}$ The commercial Circuits Management Association (CMA) was also eager to participate in the celebrations. Their Gaumont and Odeon cinema chains programmed festivals of British films, held foyer exhibitions relating to the Festival, began a nationwide search for a 'Festival Girl' and organised the broadcast of King George VI's opening speech in many of their cinemas. ${ }^{15}$ Independent cinemas also entered into the spirit of the Festival. A typical example was a Festival week at the Regal Cinema in Evesham, Worcestershire. The manager showed, among others, Great Expectations (1946), Whisky Galore! (1948) and The Red Shoes (1948). ${ }^{16}$ The BFI attempted to fill the gaps left by local arts festivals, national cinema chains and independent exhibitors by mobilising film societies and education institutes to put on film shows during the Festival period. To this end, the BFI sent out a pamphlet called How To Put on a Film Show suggesting the sort of films that could be shown, the distribution libraries that stocked them and places to obtain equipment for projecting them. They also issued three lists of recommended films for screening during the five-month Festival period which included classic British documentaries such as North Sea (1938), sturdy educational films such as Gaumont-British Instructional's Downlands (1936) and, of course, the Festival films Forward a Century and Family Portrait. ${ }^{17}$ Finally, if Festival visitors had not tired of the medium, they could purchase colour $16 \mathrm{~mm}$ film of Britain's historic buildings and pageantry and filmstrips of the Festival of Britain and London as souvenirs.

The main attraction at the Telekinema was the showcasing of new cinematic technology - stereoscopic films. This was not the first time 3-D films had been shown to the public; in I924 a programme of films had been shown in London and the USSR had already perfected stereoscopic projection without the need for the audience to wear special glasses. ${ }^{18}$ Of the four films produced for the Festival, the Norman McLaren and National Film Board of Canada's animated Technicolor films Now is the Time and Around is Around garnered the most praise. Both films used McLaren's trademark technique of direct drawing on to $35 \mathrm{~mm}$ film. The former was designed to introduce the viewer to the concept of 3 -D using shapes and sound and the latter depicted patterns made by an oscilloscope set to specially composed music. It seemed the medium was better suited to abstract form as the two live action films, Pathé Documentary Unit's $A$ Solid Explanation and International Realist's Technicolor Royal River were not well received by the critics. A Solid 
Explanation suffered from 'an assured style but inadequate material' and only two things about the film (literally!) stood out - the handshake into the audience and the giraffe's neck at London Zoo. ${ }^{19}$ Royal River, a trip down the River Thames, fared little better, the same critic pronouncing it 'very tame and stodgy' and a failure of content over form. Another critic went further, proclaiming it a 'handsome bore'. ${ }^{20}$

Nevertheless, the idea of a purpose-built cinema for 3-D sound and vision created a buzz among film enthusiasts all over the country. On the whole, the industry also responded favourably, but the prohibitive costs of producing the films and the need to re-equip theatres meant that many saw it as having very little immediate commercial impact. Oddly, the trade decided that the less said about stereophonic sound the better and treated it as little more than a novelty. ${ }^{21}$

The Painter and Poet series of four black and white art films, each under ten minutes long, was produced by the British animators John Halas and Joy Batchelor. Artists including Mervyn Peake, Henry Moore and Ronald Searle created visual impressions of eight poems, narrated by performers such as Michael Redgrave, John Laurie, Eric Portman and Stanley Holloway. It was recognised that the films were 'agreeable and enterprising [and that] they illustrate some of the possibilities of the technique even if, occasionally, they fail to realize them'. ${ }^{22}$ The most liked was Ronald Searle's interpretation of the William Cowper poem The Story of John Gilpin. One critic referred to Searle's drawing as 'so dynamic, it is difficult to realize that no picture on the screen is moving. ${ }^{23}$

Over a dozen sponsored documentary films were made for the Festival. Unfortunately there is not room here to discuss them all, so I will concentrate on five of the more high-profile productions: Forward a Century, Air Parade, Waters of Time, Family Portrait and David.

Forward a Century depicted the century between the Great Exhibition of I85I and the Festival of Britain. Critics thought it 'well photographed and edited, and written with honesty and sincerity [as well as being] unusual and imaginative'. ${ }^{24}$ After its screening at Edinburgh it was noted that 'the film as a whole is one of the most accomplished seen during the [film] Festival'. ${ }^{25}$ Britain's realist documentary tradition was represented by Air Parade. A straightforward but patriotic exposition of the history of aviation, the film concentrates on Britain's recovery since the war to become a world leader in the civil aircraft industry. The other side of the documentary tradition aesthetic as opposed to the more propagandist intentions of Air Parade - was represented by two films: Basil Wright's return to documentary directing, Waters of Time, and Humphrey Jennings's penultimate film, Family Portrait. 
Basil Wright had been an original member of the British documentary movement in the I930s. His film took a journey up the River Thames showing the activities of the Port of London by means of the narrative of a ship docking, unloading and reloading. Its images were accompanied by a complex soundtrack consisting of factual commentaries spoken by the dock master and a docker, poeticised prose and a specially composed music score. The critical press responded well to the film: the May issues of Monthly Film Bulletin and Sight and Sound thought it a 'notable film'. The former added that it was made with a range and technical finish rare in present-day documentary while the latter praised its eloquent photography, the richness of texture in the music and the care and complexity of the editing.

Humphrey Jennings's contribution, the quietly patriotic Family Portrait, related more directly to the Festival than any other film. It is subtitled 'A Film on the Theme of the Festival of Britain I95I' in approved Festival typeface over the Festival logo. The film is constructed between the opening and closing shots of a family photograph album; the family representing Britain. It proceeds to celebrate British achievements in the arts (Shakespeare), science (Darwin others) and industry (Stephenson), echoing the displays of the festival exhibitions. Jennings regards these heroes of British life with warmth. He refers to them as 'local lads who used their wits and had a good laugh, and then, like Shakespeare and Newton and Watts started something at home that went right around the globe'. The film acknowledges the contradictions of the British character: an admiration for invention versus a love of tradition, eccentricity versus practicality, domesticity versus pageantry. Overlying these paradoxes is Jennings's concept of Britain as a nation where the need for innovation (prose) meets the creative mind (poetry).

Family Portrait is a poetic but overly literal film: the evolution of British tradition, particularly democracy, is discussed over images of Runnymede, the Houses of Parliament and council committee meetings. It was well received by the press and Jennings's fellow documentarists. In retrospect it is difficult to say just how much of this praise was a result of Jennings's accidental death at the end of 1950. Many of the film's notices read like obituary eulogies. Writing in the Edinburgh Film Festival publication, Film Festival: Third Week, Edgar Anstey pronounced it to be the most important documentary film made since the war. The Monthly Film Bulletin thought it perhaps the most polished in style of all Jennings's films, adding that all the elements of the film - camerawork, editing, voice-over and music - were finely balanced, making it continuously fascinating, sharp and evocative. Today's Cinema thought it a 'lovely, lingering experience' that should 'stand as a yardstick for contemporary documentary'. Three years later in an 
article for Sight and Sound, Lindsay Anderson wrote that Family Portrait could stand beside Jennings's wartime films, but that it lacked the passion of his earlier ones. However, in a $198 \mathrm{I}$ revaluation, Anderson decided that Family Portrait, although distinctive and compositionally distinguished, was 'sentimental fiction'. He berated Jennings for his 'fantasy of the Empire' and his resort to 'The Past as a refuge'. ${ }^{26}$ Although the film's patriotism is very much of its time, it closes with the realisation that Britain belongs 'to a communion across the Atlantic and the South Seas ... [and] to the family of Europe'. While acknowledging the influence of Britain's imperial past, Jennings was well aware that its future was reliant on wider global alliances.

In contrast to the national observation of Family Portrait, Paul Dickson's film David sought to embody the spirit of Welsh society through the small south Wales community of Ammanford. Dickson had won a British Film Award in 1950 for his first film The Undefeated (1950) and used the same technique of combining drama and documentary in David. ${ }^{27}$ The film has a complex flashback narrative structure and a cast of local people, often playing their real-life roles. The local school caretaker, on whose life the film is based, plays the protagonist, Dafydd. The first flashback through the eyes of Ifor, a young villager who has returned for a visit, shows how the caretaker was an inspiration to him. The second flashback takes us through the caretaker's life beginning with his first job in the mine, which ends when he is injured in a pit accident. As he says, his life parallels that of the Welsh nation: 'most men of my age in Wales can tell the same story, getting coal was the thing, it was our wealth and in a way our destiny'. The people of Ammanford bear their hardships stoically; again, the character of Dafydd represents this. A poem he has written after the death of his son from tuberculosis is entered for the national Eisteddfod. It receives an honourable mention but does not win. The theme of the Eisteddfod, 'He who suffers conquers', is an equally fitting epithet for Dafydd, his community and the nation of Wales. The film ends with an ex-pupil from Dafydd's school, now a nationally respected scholar, returning as guest of honour to the school prize giving. Although he is a now a well-known figure, the scholar is still a part of the smaller community he was nurtured in. The most important factor, as the voice-over states, is being 'worthy of our heritage, our country, Wales'. David was uniformly praised for its naturalism and humanism. The Monthly Film Bulletin said it combined 'intelligent shaping of the narrative with an unrestrained realism'. Gavin Lambert, writing in Sight and Sound, thought it a 'success for all concerned' and it was listed as one of the magazine's 'Films of the Month'. Today's Cinema described it as 'the first really live and human film made for the Festival', adding that it was 'always 
restrained, dignified and extremely moving'. Variety commented that despite 'some too-evident artiness in the production technique, this short film registers with a moving sincerity'. Kinematograph Weekly thought it a 'charming and efficiently presented authentic life story of a Welshman'. In Wales itself The Amman Valley and East Carmarthen News concurred, stating that the caretaker's 'life story is [a] true reflection of the integrity of character that is a feature of the Welsh nation'.

The only feature officially nominated as a Festival film, The Magic Box, did not play at the Telekinema. It premièred on 18 September at the Odeon, Leicester Square, barely two weeks before the Festival closed. The cast was an extraordinary parade of British actors, many with only walk-on parts, including Laurence Olivier, Michael Redgrave, Richard Attenborough, Stanley Holloway, Eric Portman, Margaret Rutherford and Sybil Thorndike. Robert Donat played the central role of William Friese-Greene, the British inventor working on the patent for the first film camera in 1889 , whose story tied in neatly with the Festival theme of celebrating the arts, industry and science. The story of his struggle to perfect an instrument capable of photographing and projecting movement involved engineering, physics, chemistry and ultimately entertainment. Eric Ambler adapted the script from Ray Allister's 1948 biography. When published the biography had resulted in a questioning of Friese-Greene's role in the invention of cinematography. The argument continued with the production of the film, mainly between an American historian, Terry Ramsaye, and the film's producers. ${ }^{28}$ Although The Magic Box acknowledges the contribution of other cinema pioneers in its credit sequence, it portrays Friese-Greene as the true originary pioneer of cinematography. When his son returns from school with cuts to his face it transpires he has been in a fight defending his father's reputation as the inventor of moving pictures. Friese-Greene reassures the boy, but the scene ends with a melancholic Friese-Greene lamenting that the encyclopedia which his son's school friend consulted 'could have just mentioned my name. It wouldn't have hurt anybody'. The film illustrates the inventor's craving for recognition, but at the same time his possession of the English virtues of modesty, restraint and dignity. Unfortunately this was not an altogether accurate reading of the real Friese-Greene, who up until the moment of his death was still seeking acknowledgement for his achievements. ${ }^{29}$

As well as Eric Ambler, The Magic Box included other eminent British film personnel among its production team. The cinematography was the work of Technicolor's star cameraman Jack Cardiff, the music was composed by William Alwyn and conducted by Muir Matheson and the set 
designs were by John Bryan. Ronald Neame produced the film and John Boulting directed it. As is to be expected of such a prestige production, the critical press was generally positive. Many of them made the point that the film was not making a case for Friese-Greene as the sole inventor of cinematography, but merely suggesting that he should be recognised for his work alongside Edison, Le Prince, the Lumière Brothers and others. In Sight and Sound Ernest Lindgren suggested several reasons why everyone should see the film, including 'its restraint, its fidelity, its acting, its colourful period reconstructions, its humour'. However, most importantly he thought it a 'human picture of a type of individual to whom we all unknowingly owe much: the obscure, unrecognized, patient, ever-hopeful, dabbler in inventions who is prepared to sacrifice everything to his ruling passion'. The Monthly Film Bulletin noted that it was a 'leisurely, slow-paced, sober view of events with occasional ventures into near burlesque', and that it was 'excellently photographed and handsomely mounted'. The trade paper Today's Cinema thought it an 'appealing story' with 'stand-out box-office attraction ... assuring stimulating entertainment for all but the heedless'. Even the usually acerbic Richard Winnington writing in the News Chronicle thought the filmmakers had 'made a thoroughly worthy job of a difficult subject'. The American trade paper Variety summed up the film as an 'okay prestige pic [sic] for the U.S. market', adding that it was a film of 'great sincerity and integrity, superbly acted and intelligently directed'. However, despite these predictions of wide audience appeal, The Magic Box failed at the box office..$^{\circ}$

It is interesting to compare the way film was used in the $195 \mathrm{I}$ festival to the way in which the moving image was used to mark the millennium nearly fifty years later. No feature films were commissioned for showing either at the Millennium Dome in Greenwich or at cinemas around Britain. The opportunity to showcase the newly revitalised British film industry of the I990s was not taken and only two productions were made for screening at the Dome. These were a specially commissioned episode of the television series Blackadder and a four-and-a-half minute musical piece about British life called The Good Ship Citizen starring the television comedian Vic Reeves. The thirty-five-minute Blackadder: Back and Forth was shot on $35 \mathrm{~mm}$ and projected in $70 \mathrm{~mm}$ on to two 20 by 20 metre screens at the Dome's Skyscape accompanied by The Good Ship Citizen. Two major productions were incorporated into exhibitions. In the 'Timekeepers' Zone' a live action, computeranimated episode of the television series Timekeepers called Timekeepers of the Millennium was shown, and a BBC production, Navy in Action, was screened at an interactive exhibition on the Royal Navy at the University of Portsmouth. The BBC also featured all-day live coverage of the millennium 
celebrations as well as broadcasting a ten-part series surveying the last thousand years of history. New media technology was used in the production of a CD-ROM about the history of Stirling, and BBC Wales created a 'virtual art gallery' for a seven-part series on five hundred years of Welsh art. It is interesting to note that it was the television sector rather than the film industry which was called upon to produce films to reflect the cultural life of Britain for the millennium celebrations.

Film, as a whole, played a successful part in the Festival of Britain. The box office receipts of the Telekinema testify to the popularity of the stereoscopic films and also to the attraction of television, which was on the way to becoming a serious threat to cinema. It is not within the scope of this essay to discuss the place of television in the Festival, but it should be said that the film industry trade press was aware of its increasing presence. Kinematograph Weekly reported in May 195 I that the newsreel companies 'succeeded admirably in showing to a far wider public than [was] available to the Television News Service, a concise and permanent record of the event'. Although reaching a smaller share of the audience, the BBC provided five months of Festival-themed programming. As well as outside broadcasts of Festival events including the opening ceremony, they scheduled a season of Festival Theatre in their television drama slot, the light entertainment department broadcast a series on the history of British entertainment in the twentieth century and a cookery series featured regional British cooking. ${ }^{31}$

However, it would take another two years, with the coronation of Queen Elizabeth II, for television to make any real impact on British society. At the time of the Festival, film was more popular and affordable. Consequently, the opportunity to celebrate the medium was embraced by both publicly funded and privately owned sectors of the film industry. The publicly funded sector suffered a setback when almost all their funding was withdrawn, but managed to complete a good number of projects with the assistance of sponsorship. After reports in the press that the feature industry was bubbling over with ideas for Festival films, only one was completed - a cooperative venture between Rank and ABPC, amongst others, with a cast of over sixty British actors. Despite the initial problems and the limited time scale, over twenty films were made including one feature, at least fourteen documentaries, four experimental films and four stereophonic films, as well as the countless short films made for the exhibits themselves. Travelling exhibitions and local festivals of British features and documentaries ensured that the celebration of film was nationwide. Only the 3-D films were confined to screenings in London and at the Edinburgh Film Festival. Film appreciation sessions sprang up in arts clubs around the country to discuss 
the history of British film. Even so, the trade press complained that the industry should have taken greater advantage of the opportunities the Festival offered for 'the exploitation of its own wares'. ${ }^{22}$ Certainly more films could have been made, but this was not just an occasion to highlight the present, it was also a time to celebrate the past. Although the films made for the Festival of Britain did not have a lasting impact on British cinema history, a legacy of sorts does remain. The concept of the BFI establishing a production fund with government monies for experimental film-making evolved directly from the Festival and is still in operation, albeit in a different guise. The Telekinema, under the auspices of the BFI, remained on the South Bank site until the institute built a new cinema close by, the National Film Theatre, which is still in use today.

\section{Notes}

I 'The Festival', Manchester Guardian (I5 October I948).

2 There appears to be some confusion over what the South Bank cinema was actually called. Although festival literature and BFI press releases refer to it as the 'Telecinema', the name on the outside of the building was 'Telekinema'.

3 Festival Film Productions consisted of the J. Arthur Rank Organisation, Associated British Picture Corporation (ABPC), National Film Finance Corporation (NFCC), London Films/British Lion group, Sidney Bernstein, Technicolor, Kodak and Berman's (the costume rental business). From a Jack Worrow press release: BFI National Library FG/ I 29 June I950, The Magic Box microjacket.

4 The BFI Panel Sub-Committee was composed variously of Cecil King (chair), Lady Allen of Hurtwood, Anthony Asquith, Michael Balcon, Arthur Elton, John Grierson, Harry Watt, one representative each from the Kinematograph Renters' Society and the Cinematograph Exhibitors' Association, two representatives from the Association of Specialised Film Producers, Dilys Powell (Sunday Times film critic), F.A. Hoare, F. Hill, Paul Wright of the Festival Office and Oliver Bell of the British Film Institute.

5 Many other sponsored documentary films were made for the festival, such as Bristol British City (Bristol City Corporation), City of London (City of London Corporation), Home of Your Own (Hemel Hempstead Corporation), In Black and White (Bowater Paper Corporation), Model Flight (Shell), Proud Preston (Corporation of Preston), Voices Under the Sea (Cable and Wireless) and We've Come a Long Way (Anglo-Iranian Oil Company). A film about the problems in Pakistan, Kashmir Conflict made by Peter Lennox and Lawrence Mitchell, was deemed too controversial for screening. Its exhibition was banned by the LCC unless it was shown alongside a film showing the Indian point of view.

6 British Film Institute: Report on Film Activities, Festival of Britain 2957, Subject file: Festival of Britain I95 I: BFI National Library.

7 Minutes of the Third Meeting of the British Film Institute Festival of Britain I95 I Panel (I6 March I949), No. I6, Subject file: Festival of Britain I95 I: BFI National Library.

8 Douglas Railton, 'They Didn't Have This in I85I', Today's Cinema, 76, 6242 (I95I), p. 3 I.

9 The Story of the Festival of Britain, HMSO (March I952), p. I2.

IO Minutes of the Second Meeting of the British Film Institute Festival of Britain I95 I Panel, I8 February I949, No. 9 (d), H/33, Aileen and Michael Balcon Special Collection, BFI Collections.

I I Several films were made for the Land of Britain Pavilion, including Fossils Which Come to 
Life and Land Fauna and Reptiles (Signal Films), Earth in Labour (Halas and Batchelor) and Landscape Scenes (Greenpark Productions).

I2 'Festival of Britain: Five Busy Months for Projectors in Villages, Towns and Cities', Film User 5, 55 (195I), pp. 246-8.

I3 Festival of Britain 2951: The Catalogue of Activities throughout the Country, Festival of Britain Office (I95I).

I4 'Arts Club Ends Instructive Film Session', Barrow News (I4 July I95I).

I5 'Varied CMA Plans for the Festival Programme', Today's Cinema 76, 6242 (195I), p. 25.

I6 'Festival Cinema Week', Evesham Standard and West Midlands Observer (7 September I95I), p. 6.

I7 Recommended 26mm Films for Distribution during the Festival of Britain 1951: List 2 (December 1950), BFI. Subject file: Festival of Britain I951: BFI National Library.

I8 Neil Baran, 'Films in Depth', The Mini-Cinema 5, 9 (1951), p. 33.

I9 See Baran, 'Films in Depth', p. 32.

20 Times Educational Supplement (I4 September I95I), Edinburgh International Festival I95 I file, BFI National Library.

2I 'The Kine Takes an Exhibitor as Guest to the Festival's Telekinema', Kinematograph Weekly 2, 288 (I95I), p. 6.

22 Monthly Film Bulletin 18, 209 (1951), p. 284.

23 Film User 5,58 (195I), p. 405.

24 The Mini-Cinema 5, II (I951), p. 35.

25 Weekly Scotsman (6 September I95I), Edinburgh International Film Festival I95I file, BFI National Library.

26 Lindsay Anderson, 'Postscript: October I98I', in Mary Lou Jennings (ed.), Humphrey Jennings: Film-maker, Painter, Poet (British Film Institute in association with Riverside Studios, 1982), p. 59 .

27 In the documentary movement there had often been a blurring of the boundary between drama and documentary. For example: North Sea (1938), The Silent Village (1943), Highland Doctor (1943), Western Approaches (1944) and Blue Scar (1949). The last film was also shot in a Welsh mining village.

28 Research continues into the validity of Friese-Greene's place among the pioneers of moving image technology. See Alan Burton's article 'Seeing is Believing: The Magic Box' in Alan Burton et al. (eds), The Family Way: The Boulting Brothers and British Film Culture (Flicks Books, 2000), pp. I64-8.

29 See Michael Chanan, The Dream That Kicks (Routledge, 1996), pp. 92-3.

30 On 29 April 1952 The Times reported that the NFFC had sustained a loss of $£_{45}, 85$ I. 'The loss', it stated, 'arises almost wholly from the failure at the box-office of The Magic Box, the Festival of Britain film, for the production of which the corporation made a large loan. In fact, the corporation lost nearly all the money put into it.' The Magic Box microjacket, BFI National Library.

3I Cecil McGivern, 'Television and the Festival of Britain', Radio Times III, I 433 (I95I), p. 43.

32 'The Festival', Kinematograph Weekly 2259 (I95I), p. 4. 